TITLE:

\title{
TAXONOMIC STUDY ON TRITONIOPSIS ELEGANS (AUDOUIN, 1826) FROM SETO, JAPAN (NUDIBRANCHIA: DENDRONOTOIDEA)
}

\author{
$\operatorname{AUTHOR(S):~}$ \\ Baba, Kikutaro
}

CITATION:

Baba, Kikutaro. TAXONOMIC STUDY ON TRITONIOPSIS ELEGANS (AUDOUIN, 1826) FROM SETO, JAPAN (NUDIBRANCHIA : DENDRONOTOIDEA). PUBLICATIONS OF THE SETO MARINE BIOLOGICAL LABORATORY 1969, 16(6): 395-398

\section{ISSUE DATE:}

1969-03-31

URL:

http://hdl.handle.net/2433/175562

RIGHT: 


\title{
TAXONOMIC STUDY ON TRITONIOPSIS ELEGANS (AUDOUIN, 1826) FROM SETO, JAPAN (NUDIBRANCHIA : DENDRONOTOIDEA) ${ }^{1)}$
}

\author{
KiKUTARÓ BABA \\ Biological Institute, Osaka Kyoiku University, Tennoji, Osaka, Japan
}

With Plate $X X V I$

The first specimen of a dendronotoid nudibranch here concerned which had been separated from Tritoniopsis alba (BABA, 1949) of Sagami Bay and referred tentatively to the Red Sea form T. elegans in my unpublished manuscript was obtained far ago by Dr. Huzio Utinomi at Seto, Middle Japan, in July 1938. Of late years it turned out by underwater observations of the laboratory members that this nudibranch lives on an alcyonarian species (see Thомpson, 1962, p. 173) around Tôshima and Shisôjima islets, 10-12 meters deep, near the Seto Marine Biological Laboratory, and actual specimens were often kept alive in the laboratory aquarium for exhibition. I had been thus fortunate enough to study this nudibranch repeatedly. Moreover, the original accounts and figures of the type species of T. elegans appeared in "Description de l'Égypte" were recently made accessible at the library of the Tenri University, Nara. Now it seemed timely for me to establish a definite identification of this animal with the description running below.

I am grateful to Dr. H. UTinomi of the Seto Marine Biological Laboratory for the first specimen and for the identification of the host alcyonacean, ${ }^{2)}$ and to the aquarium members of the laboratory, especially to the chief curator $\mathrm{Mr}$. Chuichi ARAGA, for their kindness in giving me chances to examine live specimens and in telling me of the biology of the nudibranch. I must thank also the President of the Tenri University for the permission to consult the rare publication "Description de l'Égypte" at the University library.

\section{TAXONOMY}

Family Tritoniidae H. \& A. Adams, 1858

Genus Tritoniopsis Eliot, 1905 (= Tritoniopsilla PRUVOT-FoL, 1933)

Type: Tritoniopsis brucei ELIOT, 1905

1) Contributions from the Seto Marine Biological Laboratory, No. 505.

2) Cladiella digitulata (KLunzinger) (Japanese name: Yubinô-tosaka).

Publ. Seto Mar. Biol. Lab., XVI (6), 395-398, 1969. (Article 30) 


\title{
Tritoniopsis elegans (AudouIN, 1826)
}

\author{
(Japanese name: Yubinô-hanagasa-umiushi, n. n.)
}

Tritonia elegans Audouin, 1826, pp. 15-16 for SAvigny, 1817, pl. 2, fig. 1.

Tritoniopsilla elegans: Pruvot-Fol, 1933, pp. 108-111, pl. 4, figs. 51-55.-Red Sea; Odhner, 1936, p. 1080, figs. 12-13.- Red Sea.

Tritoniopsis gravieri VAYsSière, 1912, pp. 90-95, pl. 6, figs. 78-86.-Red Sea.

Tritoniopsilla alba: Utinomi, 1956, p. 100, pl. 50, fig. 9a-b (non BABA, 1949).-Seto, Japan.

The original description of Tritonia elegans given by Audouin (1826) was insufficient. But it appears that this species has been recovered from about the presumed type locality by subsequent authors, and redescribed. Hence it is suggested here that the present specimens from Seto are to be identified with Audouin's species despite of some almost insignificant disagreements between the two in the shades of the marblings on the back surface. They are distinguished from Tritoniopsis alba (BABA, 1949) by the presence in the latter of a series of denticles on the central tooth as well as on each of the lateral teeth of the radula.

The material for the present study consisted of the following specimens:

Sp. No. 1 (preserved). Seto, July 30, 1938.

Sp. Nos. 2-3 (living). Seto, June 13, 1962.

Sp. No. 4 (living). Seto, Sept. 4, 1964.

Sp. Nos. 5-6 (living). Seto, July 12, 1965.

Sp. Nos. 7-10 (living). Seto, Sept. 19, 1967.

Description: These specimens ranged roughly from 40 to $100 \mathrm{~mm}$ in length. Special measurements made on Sp. No. 9 after the Code system of Risso-Dominguez (1963) in tritonids are shown thus: total body-length from fringed veil to tail-tip (A) $53 \mathrm{~mm}$; body-length from veil-margin proper to tail tip (Ac) $50 \mathrm{~mm}$; mantle-width (Mx) $10 \mathrm{~mm}$; mantle-height (Hx) $7 \mathrm{~mm}$; tail-length (C) $10 \mathrm{~mm}$; width of fringed veil (E) $14 \mathrm{~mm}$; width of veil proper (V) $11 \mathrm{~mm}$; maximum length of velar papillae (Vdx) $3 \mathrm{~mm}$; rhinophore-length (R) $6 \mathrm{~mm}$; gill-length (P) $11 \mathrm{~mm}$; sole-width (B) $11 \mathrm{~mm}$.

In external aspects the specimens from Seto appear very close to the type series of Audouin's species. Velar papillae 11-12 or more; they are usually simple, rarely bearing accessory branches. Veil itself without a median notch. Rhinophore-sheaths with a crenulated edge. Back finely granulated, the sides entirely smooth when alive. The gills on back-margins are exceedingly numerous, more than 18 on each side, and the fringe-like gill-rows appear to extend anteriorly beyond the base of each rhinophore-sheath. In each row the larger and smaller gills alternate approximately with each other. Anus at about the middle of the body on the right side. Nephroproct above anus.

The general ground-colour of the back and sides varies individually from translucent whitish or yellowish white to faint pink. The velar papillae and gill twigs are 
opaque white. On the back there may occur bold irregular networks or marblings which are neither orange-red as in the type series of the species nor black as shown by VAYSSIERE but are opaque white on the present specimen series (Sp. Nos. 7-9). The sole is uniformly opaque white. The plumes of the rhinophores are tinted yellow.

The jaws are smooth on the masticatory edge. The long and narrow radula is constructed seemingly as in the type series of the species, although unfortunately details of the radular teeth were not given for them by the original author. On the present specimens from Seto, the radular formulae are about $48 \times 6-10.1$. 6-10 in Sp. No. 1, $42 \times 7-8.1 .7-8$ in Sp. No. 4, and $57 \times 8.1 .8$ in Sp. No. 5, respectively. The central tooth is narrow, and always provided with a smooth median cusp. The first lateral is undifferentiated. All the laterals are filiform, and as a rule non-denticulated (as on the figures of PRUVOT-FoL, 1933), or very rarely there may be traces of faint denticles on some of the inner lateral teeth(denticles on these laterals were more clearly shown by VAYssière, 1912). The right liver is completely united with the left one. The stomach has a girdle of pyloric folds which show no sign of formation of any chitinous plates. The spermatocyst is spherical. The penis in a contracted state is a short conical structure without apical stylet. These characters of the genitalia do not differ materially from those given by ODHNER, 1936. The ampulla is long and winding.

Egg-laying by Sp. Nos. 7-10 was observed during the last part of September, 1967 in an aquarium tank. The yellowish white egg mass consists of a long, thickly looping string which is sinistrally coiled in $4 \frac{1}{2}-5 \frac{1}{2}$ turns. In surface view the whole mass assumes a circular patch measuring about $45-50 \mathrm{~mm}$ across. The egg-string itself is formed approximately as in Tritonia (see THOMPson, 1961, p. 13). A single egg-cell is contained within each capsule.

\section{REFERENCES}

Audouin, V. 1826. Explication sommmaire des planches de mollusques de l'Égypte et de la Syrie, publiées par J. C. SAvigny, membre de l'Institut, in: Description de l'Égypte, ou Recueil des observations et des recherches qui ont été faites en Égypte pendant l'expédition de l'armée française, publié par les ordres de sa Majesté l'Empereur Napoléon le Grand. Histoire naturelle, tom. I, pt. 4.

BABA, K. 1949. Opisthobranchia of Sagami Bay collected by His Majesty the Emperor of Japan. Iwanami Shoten, Tokyo.

Er.10т, C. 1905. The Nudibranchiata of the Scottish National Antarctic Expedition. Trans. Roy. Soc. Edinburgh, vol. 41, pt. 3, no. 22. (p. 530, Tritoniopsis brucei)

HAAs, F. 1920. Opisthobranchier aus verschiedenen warmen Meeren. Arch. Molluskenk., Jahrg. 52, Heft 3. (not seen)

Hurst, A. 1967. The egg masses and veligers of thirty northeast Pacific opisthobranchs. The Veliger, vol. 9, no. 3. (p. 266, Tritonia exsulans)

Leмche, H. 1961. Tritonia Cuvier, 1797 (Gastropoda); proposed designation of a type-species under the plenary powers. Bull. zool. Nomencl., vol. 18, pt. 4. (p. 286, Tritoniidae)

Odhner, N. 1936. Nudibranchia Dendronotacea. A revision of the system. Mém. Mus. Roy. d'Hist. Nat. Belgique, ser. 2, fasc. 3. __ 1963. On the taxonomy of the family Tritoniidae 
(Mollusca: Opisthobranchia). The Veliger, vol. 6, no. 1. (p. 51, Trochuina and Tritoniopsis) Pruvot-Fol, A. 1933. Mission Robert Ph. Dollfus en Égypte. Opisthobranchiata. Mém. I'Inst. d'Égypte, tom. 21.

Risso-Dominguez, C. J. 1963. Measuring nudibranchs: a standardization for descriptive purposes. Proc. malac. Soc. London, vol. 35, pt. 5.

Savigny, J. C. 1817. Gastéropodes, in: Description de l'Égypte, ou Recueil des observations et des recherches qui ont été faites en Égypte pendant l'expéditon de l'armée française, publié par ordre du Gouvernement. Histoire naturelle, planches, tom. II.

Thompson, T. E. 1961. The structure and mode of functioning of the reproductive organs of Tritonia hombergi (Gastropoda Opisthobranchia). Quart. Journ. Micr. Sci., vol. 102, pt. 1. —— 1962. Studies on the ontogeny of Tritonia hombergi Cuvier (Gastropoda Opisthobranchia). Phil. Trans. Roy. Soc. London, ser. B, no. 722, vol. 245.

Utinomi, H. 1956. Coloured illustrations of sea shore animals of Japan. Hoikusha, Osaka.

VAYssière, A. 1912. Recherches zoologiques et anatomiques sur les opisthobranches de la Mer Rouge et du Golfe d'Aden. Ann. Fac. Sci. Marseille, tom. 20, Suppl.

White, K. M. 1951. On a collection of molluscs, mainly nudibranchs from the Red Sea. Proc. malac. Soc. London, vol. 28, pt. 6. (p. 241, Tritoniopsis gravieri)

\section{EXPLANATION OF PLATE XXVI}

Tritoniopsis elegans (AudouIN) collected from Seto, Kii, Japan.

Fig. 1. Living animal in an actively crawling position. Sp. No. 2. Length (Ac) $50 \mathrm{~mm}$. General integument translucent whitish.

Fig. 2. Ventral view of head-veil and foot. Sp. No. 2. a. tentacles.

Fig. 3. Right side view of an actively creeping animal. Sp. No. 9. Length (Ac) $50 \mathrm{~mm}$. General integument yellowish white. a. genital orifice, b. nephroproct, c. anus.

Fig. 4. General view of the visceral organs. Main material: Sp. No. 4. a. salivary glands, b. penial sac, c. accessory temale glands, d. right liver, e. reno-pericardial canal, f. nephroproct, g. anus, h. left liver, i. pyloric girdle of folds, j. stomach, k. oesophagus.

Fig. 5. Paired jaw-plates from outside $(\times 7)$. Sp. No. 5. a. left jaw, b. right jaw.

Fig. 6. A half-row of radula $(\times 210)$. Sp. No. 5. a. central tooth, b. lateral teeth.

Fig. 7. Part of pyloric girdle of folds $(\times 15)$. Sp. No. 4.

Fig. 8. Genital organs from above. Sp. No. 5. a. penis within a penial sac, b. spermatocyst, c. ampulla, d. accessory female glands.

Fig. 9. Penis (a) within a penial sac, and a vas deferens (b). Sp. No. 5.

Fig. 10. Penis in fresh $(\times 17)$. Sp. No. 8. 
Publ. Seto Mar. Biol. Lab., XVI (6), 1969.
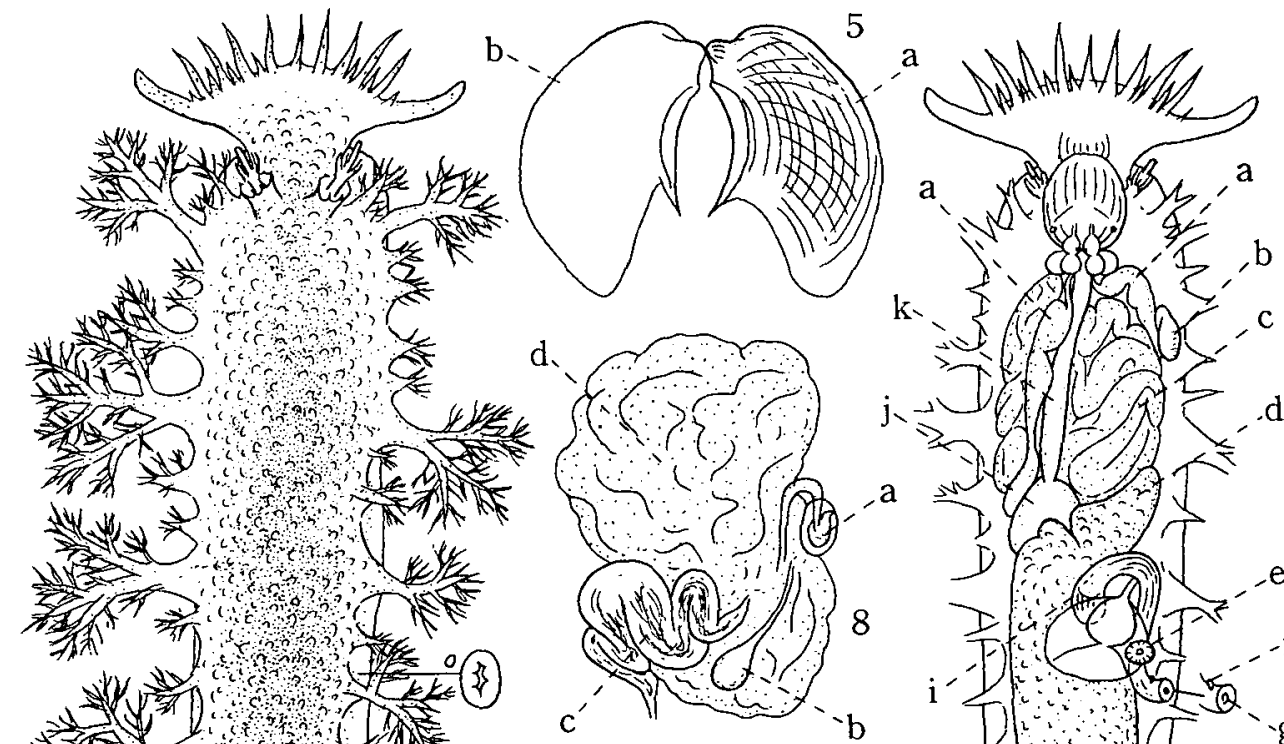

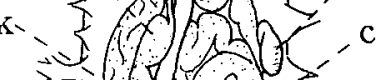
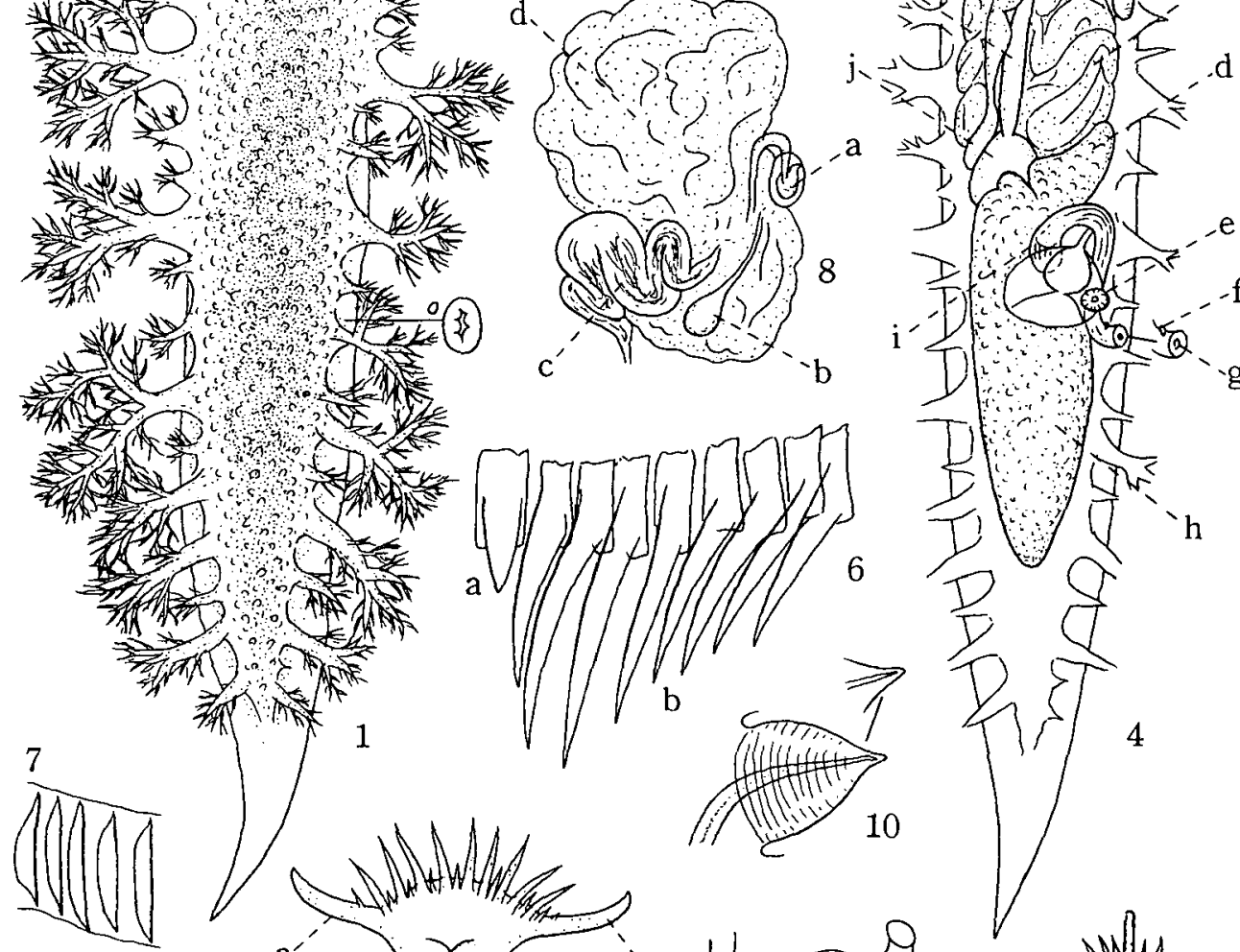